\title{
PEMBENTUKAN KETERAMPILAN BERPIKIR KREATIF PADA PEMBELAJARAN MATEMATIKA MODEL SAVI BERBASIS DISCOVERY STRATEGY MATERI DIMENSI TIGA KELAS X.
}

\author{
Hendri Handoko \\ Tadris Matematika, IAIN Syekh Nurjati Cirebon \\ J1. Perjuangan By Pass Sunyaragi Kota Cirebon \\ handoko.hendri@ymail.com
}

\begin{abstract}
ABSTRAK
Pembelajaran matematika materi dimensi tiga sering mengalami kesulitan, salah satu faktor penyebabnya adalah karena rendahnya kreativitas siswa dalam belajar. Salah satu alternatif yang diberikan untuk menyelesaikan permasalahan tersebut adalah dengan cara menentukan strategi pembelajaran yang inovatif. Salah satu pembelajaran inovatif yang akan dijadikan alternatif untuk mengatasi permasalahan tersebut yaitu pembelajaran model SAVI berbasis discovery strategy yang diartikan sebagai teknik pengajaran yang melibatkan semua indera siswa dalam mencari dan menemukan suatu konsep matematika melalui cara berpikir kreatif. Kegiatan pembelajaran ini memfokuskan siswa pada proses penemuan suatu konsep matematika. Tujuan dari penelitian ini adalah untuk menganalisis hasil dari proses yang berdampak pada pembentukan karakter kreatif pada diri siswa pada pembelajaran matematika materi dimensi tiga dengan pendekatan model SAVI berbasis discovery strategy. Subjek penelitian diambil dari 6 siswa yang memiliki kemampuan yang berbeda (heterogen) yaitu dengan pengelompokan kelompok atas (kemampuan tinggi), tengah (kelompok sedang), dan bawah (kelompok bawah). Teknik Pengambilan data diperoleh dengan observasi, wawancara, dokumentasi. Instrumen yang digunakan lembar observasi dan pedoman wawancara, dokumentasi. Sedangkan teknik pengolahan data dengan uji gain dan triangulasi. Hasil pengamatan kemandirian pada penelitian ini menunjukan bahwa rata-rata peningkatan karakter kreatif siswa dari pertemuan I sampai V pada subjek terpilih dihasilkan sebesar 78,20 artinya peningkatan pembentukan pada kriteria baik.
\end{abstract}

Kata Kunci: Pembelajaran Model SAVI berbasis discovery strategy, Keterampilan Berpikir Kreatif

\section{PENDAHULUAN}

Salah satu ciri dari pembelajaran matematika masa kini adalah penyajiannya didasarkan pada teori-teori psikologi pembelajaran yang dilahirkan oleh para pakar pendidikan. Dengan menguasai psikologi pembelajaran, guru bisa mengetahui kemampuan yang telah dimiliki siswa dan bagaimana proses berpikirnya. Selain itu guru juga dapat mengetahui bagaimana menciptakan kegiatan pembelajaran sesuai dengan kondisi siswa dan tujuan pengajaran.

Peran matematika sebagai induk ilmu oengetahuan, alat bantu, pembimbing pola pikir maupun pembentuk sikap oleh sebab itu proses pembelajaran matematika harus dapat dilakukan dengan baik. Matematika dapat difungsikan untuk mengembangkan kemampuan berfikir yang sistematis, logis, kreatif, disiplin dan kerjasama yang efektif dalam kehidupan yang modern dan kompetitif. Begitu pentingnya peran matematika dalam kehidupan manusia maka dibutuhkan strategi dalam pembelajarannya.

Hal penting yang menjadi catatan Postman (2002 : 1) bahwa dalam menyelenggarakan pendidikan ada dua persoalan yang harus diselesaikan, Pertama menyangkut keahlian teknis yaitu cara (metode) penyampaian, kapan, dimana dan bagaimana metode tersebut dilaksanakan. Kedua persoalan yang bersifat metafisik yaitu menyangkut motivasi, kreativitas, psikologi, kemauan dari siswa maupun guru.

Persoalan menyangkut keahlian teknis berupa cara penyampaian (model/metode) menuntut seorang guru 
untuk dapat melakukan inovasi dalam memilih metode pembelajaran. Kenyataan dilapangan menunjukkan bahwa banyak terdapat guru yang belum mampu melaksanakan pembelajaran dengan pendekatan metode yang disesuaikan oleh kemampuan siswa, bahkan masih ada guru yang sama sekali tidak pernah menerapkan model pembelajaran. Akibatnya fungsi guru yang seharusnya dapat mengarahkan, membimbing dan memberikan jalan keluar agar segala sesuatu yang dilakukan oleh siswa tidak dapat berjalan dengan baik dan maksimal.

Persoalan kedua menyangkut metafisik diartikan sebagai faktor yang berada dalam diri siswa, yaitu persoalan psikologis. Salah satu persoalan metafisik yang sering ada dalam diri siswa adalah motivasi siswa dalam belajar. Indikator bahwa siswa mempunyai motivasi yang tinggi dalam pembelajaran dapat dilihat dari kesadaran diri untuk mencari atau menemukan hal-hal baru sesuai dengan daya nalar dan kritis serta kreatif siswa. Dalam kegiatan pembelajaran, kreativitas siswa sangat penting karena kreatif diartikan sebagai berfikir melakukan sesuatu untuk menghasilkan atau hasil baru dari sesuatu yang telah dimiliki (Pusat Kurikulum dan Perbukuan Kementerian Pendidikan Nasional, 2011). Sehingga perlu didesain pembelajaran yang lebih melibatkan metafisik siswa agar pembelajaran tersebut menjadi lebih bermakna. Peran guru hanya sebagai fasilitator pendidikan yang bertugas untuk membimbing, mengarahkan dan memotivasi siswa serta jika diperlukan untuk memberikan pemahaman baru kepada siswa.

Kenyataan

dilapangan menyebutkan bahwa pembelajaran saat ini masih didominasi oleh paradigma teacher centered. Pembelajaran yang bersifat searah ini membuat siswa selalu bergantung pada pekerjaan guru, sehingga selama pembelajaran berlangsung siswa cenderung pasif. Siswa hanya mendengarkan, mencatat dan dituntut menghafal lalu disuruh mengerjakan soalsoal latihan. Sehingga menyebabkan siswa menjadi bosan dengan pelajaran matematika, karena siswa tidak dilibatkan secara aktif dalam proses belajar.

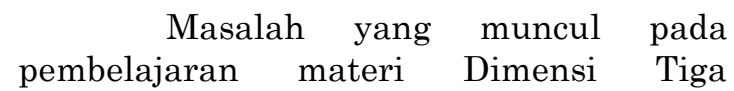
diantaranya, (1) Pemahaman gambar dan Dimensi Tiga dalam bidang dimensi dua membutuhkan tingkat abstraksi yang cukup tinggi; (2) Konsep-konsep yang harus diberikan kepada siswa juga mempunyai tingkat kesulitan yang tinggi karena harus dikaitkan dengan konsep-konsep lain dalam matematika seperti trigonometri dan segitiga; (3) Pola dan metode pengajaran yang digunakan masih lebih banyak menggunakan metode ceramah atau strategi konvensional; (4) Media dan sumber belajar yang digunakan masih sangat terbatas, baik dari sisi kuantitas maupun kualitas. Oleh karena itu, siswa cenderung merasa kesulitan dalam memahami materi ini sehingga tingkat keberhasilan atau prestasi belajar siswa pada materi ini relatif rendah. Siswa mengalami kesulitan dalam menganalisa, menggambar dan memahami konsep untuk menyelesaikan soal-soal cerita dimensi tiga karena minimnya kreativitas siswa dalam memecahkan masalah. Menurut Baker dkk (2001), kreativitas dibutuhkan siswa dan dianggap penting untuk meningkatkan kapasitas siswa serta merangsang peningkatan kemampuan prestasi akademik. Oleh karena itu dibutuhkan strategi agar pembelajaran matematika diorientasikan pada kegiatan pembentukan kreativitas siswa.

Menurut Davis (Siswono, 2008) terdapat 6 alasan mengapa pembelajaran matematika perlu menekankan pada kreativitas, yaitu: (1) Matematika begitu kompleks dan luas untuk diajarkan dengan hafalan, (2) Siswa dapat menemukan solusi-solusi yang asli (original) saat memecahkan masalah, (3) Guru perlu merespon konstribusi siswa yang asli dan mengejutkan (surprised), (4) Pembelajaran matematika dengan hafalan dan masalah rutin akan membuat siswa tidak termotivasi dan mengurangi kemampuannya, (5) Keaslian merupakan sesuatu yang perlu diajarkan, seperti membuat pembuktian asli dari teoremateorema, (6) Kehidupan nyata sehari-hari memerlukan matematika serta memerlukan kreativitas dalam menyelesaikannya.

Tayor dkk (Wang 2011) mengatakan bahwa potensi berpikir kreatif 
ada pada semua orang dan dapat ditingkatkan melalui pembelajaran sehingga dalam dunia pendidikan berpikir kreatif dianggap sebagai elemen untuk dapat disinergikan dengan pencapaian tujuan belajar mengajar. Sifat dan sikap siswa dapat dibentuk dengan memunculkan daya imajinasi dan daya kreatif sebagai basis untuk menemukan hal-hal baru, inovatif serta kritis.

Model pembelajaran SAVI dapat digunakan untuk mengatasi kurangnya daya kreatif siswa karena pembelajaran SAVI menekankan bahwa belajar haruslah memanfaatkan semua alat indra yang dimiliki peserta didik. Istilah SAVI sendiri adalah kependekan dari: Somatic yang bermakna gerakan tubuh (hands-on, aktivitas fisik) di mana belajar dengan mengalami dan melakukan; Auditory yang bermakna bahwa belajar haruslah dengan melalui mendengarkan, menyimak, berbicara, presentasi, argumentasi, mengemukakan pendapat, dan menanggapi; Visualization yang bermakna belajar haruslah menggunakan indra mata melalui mengamati, menggambar, mendemonstrasikan, membaca, menggunakan media dan alat peraga; dan Intellectualy yang bermakna bahwa belajar haruslah menggunakan kemampuan berpikir (minds-on) belajar haruslah dengan konsentrasi pikiran dan berlatih menggunakannya melalui bernalar, menyelidiki, mengidentifikasi, menemukan, mencipta, mengkonstruksi, memecahkan masalah, dan menerapkan.

\section{KAJIAN PUSTAKA}

\section{a. Keterampilan Berpikir Kreatif}

Keterampilan merupakan kemampuan berbuat sesuatu dengan baik. Keterampilan berpikir kreatif (creative thinking) yaitu keterampilan individu dalam menggunakan proses berpikirnya untuk menghasilkan gagasan yang baru, konstruktif berdasarkan konsep-konsep dan prinsip-prinsip yang rasional maupun persepsi, dan intuisi individu (Ahmadi, dkk, 2011: 111). Keterampilan berpikir kreatif dibangun oleh konsep-konsep yang sudah tertanam pada diri siswa yang kemudian konsep serta prinsip-prinsip yang sudah ada tersebut diaplikasikan siswa dalam menyelesaikan suatu permasalahan.

Sumalee (2012) menyatakan bahwa kreatif adalah perilaku seseorang untuk menemukan hal-hal baru yang digunakan dalam memecahkan masalah. Dengan demikian, berpikir kreatif adalah kemampuan otak seseorang pada tingkat tertinggi yang diperlukan untuk membangun pengetahuan pada dirinya.

Manusia kreatif acapkali memiliki kehidupan sosial yang mengasyikkan dan merangsang berinteraksi dengan banyak orang, dengan demikian mereka terus menerus belajar dan berbuat dengan ide baru (Ayan, 2002 : 26)

Menurut Davis (Mahmud, 1990), apabila ditinjau dari pengertian dasar tentang kreativitas dapat dilihat dari ciriciri orang kreatif yaitu meliputi tujuan, nilai dan sejumlah sifat-sifat pribadi yang bersama-sama membekali seseorang untuk berfikir bebas, luwes dan imajinatif.Inti dari semua konsep kreativitas adalah adanya unsur kebaruan.Hasil dari kreativitas berwujud cara-cara berpikir atau melakukan sesuatu yang bersifat baru, orisinil dan bebas.

Dalam dunia pendidikan kreativitas dianggap sebagai elemen untuk dapat disinergikan dengan pencapaian tujuan belajar mengajar. Sifat dan sikap siswa dapat dibentuk dengan memunculkan daya imajinasi dan daya kreatif sebagai basis untuk menemukan hal-hal baru, inovatif serta kritis.

Seorang siswa yang mampu berpikir kreatif harus dapat diarahkan melalui proses yang berkesinambungan. Menurut Wallas (Munandar, 2002: 59) langkah-langkah proses berpikir kreatif meliputi empat tahap, yaitu;

1) Tahap Persiapan, yaitu proses tahapan seseorang mempersiapkan diri untuk memecahkan masalah dengan belajar berpikir, mencari jawaban, bertanya kepada orang lain dan sebagainya.

2) Tahap Inkubasi, yaitu kegiatan mencari dan menghimpun data/informasi tidak dilanjutkan. Pada tahap ini, individu seakan-akan melepaskan diri untuk sementara dari masalah tersebut dalam arti bahwa ia tidak memikirkan masalahnya secara sadar, tetapi menyimpannya dalam alam pra-sadar. Tahap inkubasi 
penting artinya penting artinya dalam proses timbulnya inspirasi yang merupakan titik mula dari suatu penemuan atau kreasi baru yang berasal dari daerah pra-sadar atau timbul dalam keadaan ketidaksadaran penuh.

3) Tahap Iluminasi, adalah tahap timbulnya "insight" atau "aha-erlebnis". Saat timbulnya inspirasi atau gagasan baru, beserta proses-proses psikologis yang mengawali dan mengikuti munculnya inspirasi atau gagasan baru.

4) Tahap Verifikasi, atau disebut juga tahap evaluasi adalah tahap dimana ide atau kreasi baru ter sebut harus diuji terhadap realitas. Disini diperlukan pemikiran kritis dan konvergen. Dengan kata lain, proses divergen (pemikiran kreatif) harus diikuti oleh proses konvergensi (pemikiran kritis)

Keterampilan berpikir kreatif dalam penelitian ini sebagaimana yang diungkapkan oleh Munandar (2009: 192) antara lain; (1) Keterampilan berpikir lancar (Fluency), (2) Keterampilan berpikir luwes (Flexibility), (3) Keterampilan berpikir orisinil (Originality), Keterampilan memperinci (Elaboration), (5) Keterampilan mengevaluasi (Evaluation). Sedangkan menurut Arikunto (2012: 198) menyatakan bahwa pengukuran ranah psikomotorik dilakukan terhadap hasilhasil belajar yang berupa penampilan.

Adapun Indikator keterampilan berpikir kreatif dapat dilihat pada tabel dibawah ini:

Tabel. 1

Indikator Keterampilan Berpikir Kreatif

\begin{tabular}{|c|c|}
\hline Jenis Ketrampilan Berpikir Kreatif & Indikator \\
\hline Keterampilan berpikir lancar (Fluency) & $\begin{array}{l}\text { 1. Mengajukan banyak pertanyaan. } \\
\text { 2. Menjawab dengan sejumlah jawaban jika } \\
\text { ada pertanyaan. } \\
\text { 3. Mempunyai banyak gagasan mengenai } \\
\text { suatu masalah. } \\
\text { 4. Lancar mengungkapkan gagasan- } \\
\text { gagasannya. } \\
\text { 5. Bekerja lebih cepat dan melakukan lebih } \\
\text { banyak daripada anak-anak lain. } \\
\text { 6. Dapat dengan cepat melihat kesalahan atau } \\
\text { kekurangan pada suatu objek atau situasi. }\end{array}$ \\
\hline Keterampilan berpikir luwes (Flexibility) & $\begin{array}{l}\text { 1. Memberikan aneka ragam penggunaan yang } \\
\text { tidak lazim terhadap suatu objek. } \\
\text { 2. Memberikan macam-macam penafsiran } \\
\text { (interpretasi) terhadap suatu gambar, } \\
\text { cerita, atau masalah. } \\
\text { 3. Menerapkan suatu konsep atau asas dengan } \\
\text { cara yang berbeda-beda. } \\
\text { 4. Memberi pertimbangan terhadap situasi, } \\
\text { yang berbeda dari yang diberikan orang } \\
\text { lain. } \\
\text { 5. Dalam membahas/mendiskusikan suatu } \\
\text { situasi selalu mempunyai posisi yang } \\
\text { berbeda atau bertentangan dari mayoritas } \\
\text { kelompok. } \\
\text { 6. Jika diberikan suatu masalah biasanya } \\
\text { memikirkan macam-macam cara yang } \\
\text { berbeda-beda untuk menyelesaikannya. } \\
\text { 7. Menggolongkan hal-hal menurut pembagian } \\
\text { (kategori) yang berbeda-beda. } \\
\text { 8. Mampu mengubah arah berpikir spontan. }\end{array}$ \\
\hline
\end{tabular}




\begin{tabular}{|c|c|}
\hline Keterampilan berpikir orisinil (Originality) & $\begin{array}{l}\text { 1. Memikirkan masalah-masalah atau hal-hal } \\
\text { yang tidak pernah terpikirkan oleh orang } \\
\text { lain. } \\
\text { 2. Mempertanyakan cara-cara lama dan } \\
\text { berusaha memikirkan cara-cara baru. } \\
\text { 3. Memilih a-simetri dalam menggambar atau } \\
\text { membuat disain. } \\
\text { 4. Memiliki cara berpikir yang lain dari yang } \\
\text { lain } \\
\text { 5. Mencari pendekatan yang baru dari yang } \\
\text { stereotip. } \\
\text { 6. Setelah membaca atau mendengar gagasan- } \\
\text { gagasan, bekerja untuk menemukan } \\
\text { penyelesaian yang baru. } \\
\text { Lebih senang mensintesis daripada } \\
\text { menganalisa situasi. }\end{array}$ \\
\hline Keterampilan memperinci (Elaboration) & $\begin{array}{l}\text { 1. } \begin{array}{l}\text { Mencari arti yang lebih mendalam terhadap } \\
\text { jawaban atau pemecah masalah dengan } \\
\text { melakukan langkah-langkah } \\
\text { terperinci. }\end{array} \\
\text { 2. Mang } \\
\text { orang lain. } \\
\text { 3. Mencoba atau menguji detil-detil untuk } \\
\text { melihat arah yang akan ditempuh. } \\
\text { 4. Mempunyai rasa keindahan yang kuat } \\
\text { sehingga tidak puas dengan penampilan } \\
\text { yang kosong atau sederhana. } \\
\text { 5. Menambahkan garis-garis, warna-warna, } \\
\text { dan detil-detil (bagian-bagian) terhadap } \\
\text { gambarnya sendiri atau gambar orang lain. }\end{array}$ \\
\hline Keterampilan mengevaluasi (Evaluation) & $\begin{array}{l}\text { 1. Memberi pertimbangan atas dasar sudut } \\
\text { pandangnya sendiri. } \\
\text { 2. Menentukan pendapat sendiri mengenai } \\
\text { suatu hal. } \\
\text { 3. Menganalisis masalah atau penyelesaian } \\
\text { secara kritis dengan selalu menanyakan } \\
\text { "Mengapa?". } \\
\text { 4. Mempunyai alasan (rasional) yang dapat } \\
\text { dipertanggungjawabkan untuk mencapai } \\
\text { suatu keputusan. } \\
\text { 5. Merancang suatu rencana kerja dari } \\
\text { gagasan-gagasan yang tercetus. } \\
\text { 6. Pada waktu tertentu tidak menghasilkan } \\
\text { gagasan-gagasan tetapi menjadi peneliti } \\
\text { atau penilai yang kritis. } \\
\text { 7. Menentukan pendapat dan bertahan } \\
\text { terhadapnya. }\end{array}$ \\
\hline
\end{tabular}

\section{b. Pembelajaran Model SAVI}

Pembelajaran SAVI menganut aliran ilmu kognitif modern yang menyatakan belajar yang paling baik adalah melibatkan emosi, seluruh tubuh, semua indera, dan segenap kedalaman serta keluasan pribadi, menghormati gaya belajar individu lain dengan menyadari bahwa orang belajar dengan cara-cara yang berbeda. Mengkaitkan sesuatu dengan 
hakikat realitas yang nonlinear, nonmekanis, kreatif dan hidup.

Sesuai dengan singkatan dari SAVI, yaitu: Somatic, Auditory, Visualizationdan Intellectualy, maka karakteristiknya ada empat bagian yaitu:

\section{1) Somatic}

"Somatic" berasal dari bahasa yunani yaitu tubuh - soma.Jika dikaitkan dengan belajar maka dapat diartikan belajar dengan bergerak dan berbuat.Sehingga pembelajaran somatic adalah pembelajaran yang memanfaatkan dan melibatkan tubuh (indera peraba, kinestetik, melibatkan fisik dan menggerakkan tubuh sewaktu kegiatan pembelajaran berlangsung).

\section{2) Auditory}

Belajar dengan berbicara dan mendengar.Pikiran kita lebih kuat daripada yang kita sadari, telinga kita terus menerus menangkap dan menyimpan informasi bahkan tanpa kita sadari.Ketika kita membuat suara sendiri dengan berbicara beberapa area penting di otak kita menjadi aktif. Hal ini dapat diartikan dalam pembelajaran siswa hendaknya mengajak siswa membicarakan apa yang sedang mereka pelajari, menerjemahkan pengalaman siswa dengan suara. Mengajak mereka berbicara saat memecahkan masalah, membuat model, mengumpulkan informasi, membuat rencana kerja, menguasai keterampilan, membuat tinjauan pengalaman belajar, atau menciptakan makna-makna pribadi bagi diri mereka sendiri.

\section{3) Visualization}

Belajar dengan mengamati dan menggambarkan. Dalam otak kita terdapat lebih banyak perangkat untuk memproses informasi visual daripada semua indera yang lain. Setiap siswa yang menggunakan visualnya lebih mudah belajar jika dapat melihat apa yang sedang dibicarakan seorang penceramah atau sebuah buku atau program komputer. Secara khususnya pembelajar visual yang baik jika mereka dapat melihat contoh dari dunia nyata, diagram, peta gagasan, ikon dan sebagainya ketika belajar.

\section{4) Intellectualy}

Belajar dengan memecahkan
masalah dan merenung.Tindakan
pembelajar yang melakukan
dengan pesuatu

ketika menggunakan kecerdasan untuk merenungkan suatu pengalaman dan menciptakan hubungan, makna, rencana, dan nilai dari pengalaman tersebut.Hal ini diperkuat dengan makna intelektual adalah bagian diri yang merenung, mencipta, dan memecahkan masalah.

Model pembelajaran SAVI dapat digunakan sebagai alternatif untuk menumbuhkan sikap kreatif siswa karena pada pembelajaran model SAVI Pembelajaran SAVI menekankan bahwa belajar memanfaatkan semua alat indra yang dimiliki siswa.

\section{c. Discovery Strategy}

Discovery strategy merupakan salah satu metode yang memungkinkan para anak didik terlibat langsung dalam kegiatan belajar mengajar, sehingga mampu menggunakan proses mentalnya untuk menemukan suatu konsep atau teori yang sedang dipelajari (Illahi, 2012: 33)

Aplikasi pembelajaran discovery strategy menitikberatkan pada kemampuan anak didik dalam memecahkan persoalan yang dihadapi pada saat proses pembelajaran melalui pendekatan inkuiri. Selain itu, discovery strategy juga juga menekankan pada proses pengembangan diri yang menuntut mereka bisa mengolah pikiran dan mengoptimalkan potensinya yang terpendam.

Hamdani (2010: 184) mengatakan bahwa discovery strategy adalah proses mental ketika siswa mengasimilasikan suatu konsep atau suatu prinsip. Proses mental tersebut antara lain, mengamati, menjelaskan, mengelompokkan, membuat kesimpulan dan sebagainya.

\section{METODE PENELITIAN}

Penelitian ini merupakan
penelitian kualitatif dengan subjek
penelitian enam siswa pilihan. Instrumen
penelitian yang digunakan untuk
mengumpulkan data terdiri dari lembar
observasi ketrampilan berfikir kreatif dan
pedoman wawancara. r Teknik
pengumpulan data dengan observasi,
wawancara dan dokumentasi. Analisis
data dengan menggunakan uji gain dan
triangulasi.


Analisis data validitas instrumen yaitu data hasil penilaian para ahli untuk setiap aspek berdasarkan skor rata-rata. Analisis data keterampilan berpikir kreatif diperoleh melalui pengamatan dianalisa dengan menggunakan rating scale. Skor tertinggi tiap butir pertanyaan adalah 5 dan terendah 1.

\section{HASIL DAN PEMBAHASAN}

Pengambilan data keterampilan berpikir kreatif dilakukan melalui pengamatan dan wawancara. Teknik pengambilan data melalui pengamatan yaitu pengamat atau observer melakukan pengamatan serta memberi penilaian terhadap keterampilan berpikir kreatif selama proses kegiatan belajar dengan menggunakan lembar observasi. Sedangkan proses wawancara dilakukan setelah kegiatan pembelajaran berakhir dengan tujuan untuk memperoleh data tentang kendala yang dihadapi siswa pada saat pembelajaran. Data hasil wawancara digunakan sebagai masukan bagi guru agar pada kegiatan pembelajaran berikutnya dapat berjalan lebih baik lagi Pengamatan keterampilan berpikir kreatif dan wawancara difokuskan pada 6 siswa pilihan yang dipilih melalui perangkingan. Pemilihan siswa berdasarkan keterwakilan kemampuan kognitif dari hasil ulangan harian matematika antara kelompok siswa kelas atas, kelas menengah dan bawah. Masingmasing kelompok dipilih dua orang siswa di mana responden atau subyek 1 dan 2 diperoleh dari siswa yang kemampuannya tinggi (kelompok atas) dengan kode S-01 dan S-02, subyek 3 dan 4 dari siswa yang kemampuannya sedang (kelompok menengah) dengan kode S-03 dan S-04 sedangkan subyek 5 dan 6 dari siswa yang kemampuannya rendah (kelompok bawah) dengan kode S-05 dan S-06. Data yang terkumpul dari hasil pengamatan maupun wawancara kemudian diolah dan dianalisa secara deskriptif.

Indikator

pencapaian

keterampilan berpikir kreatif sebelum atau sesudah kegiatan pembelajaran berlangsung menggunakan model SAVI berbasis discovery strategy yang dilakukan terhadap 6 siswa pilihan meliputi; Fluency (Keterampilan berpikir lancar), Flexibility (Keterampilan berpikir luwes), Originality (Keterampilan berpikir orisinil), Elaboration (Keterampilan dalam memperinci), Evaluation (Keterampilan mengevaluasi)

Setelah melakukan observasi/pengamatan secara langsung, peneliti dapat menganalisis tentang keterampilan berpikir kreatif yang dimiliki masingmasing subjek penelitian.

Contoh data pengamatan keterampilan berpikir kreatif subyek 3 (S03) dari pertemuan I sampai pertemuan $\mathrm{V}$ disajikan dalam bentuk gambar berikut: 


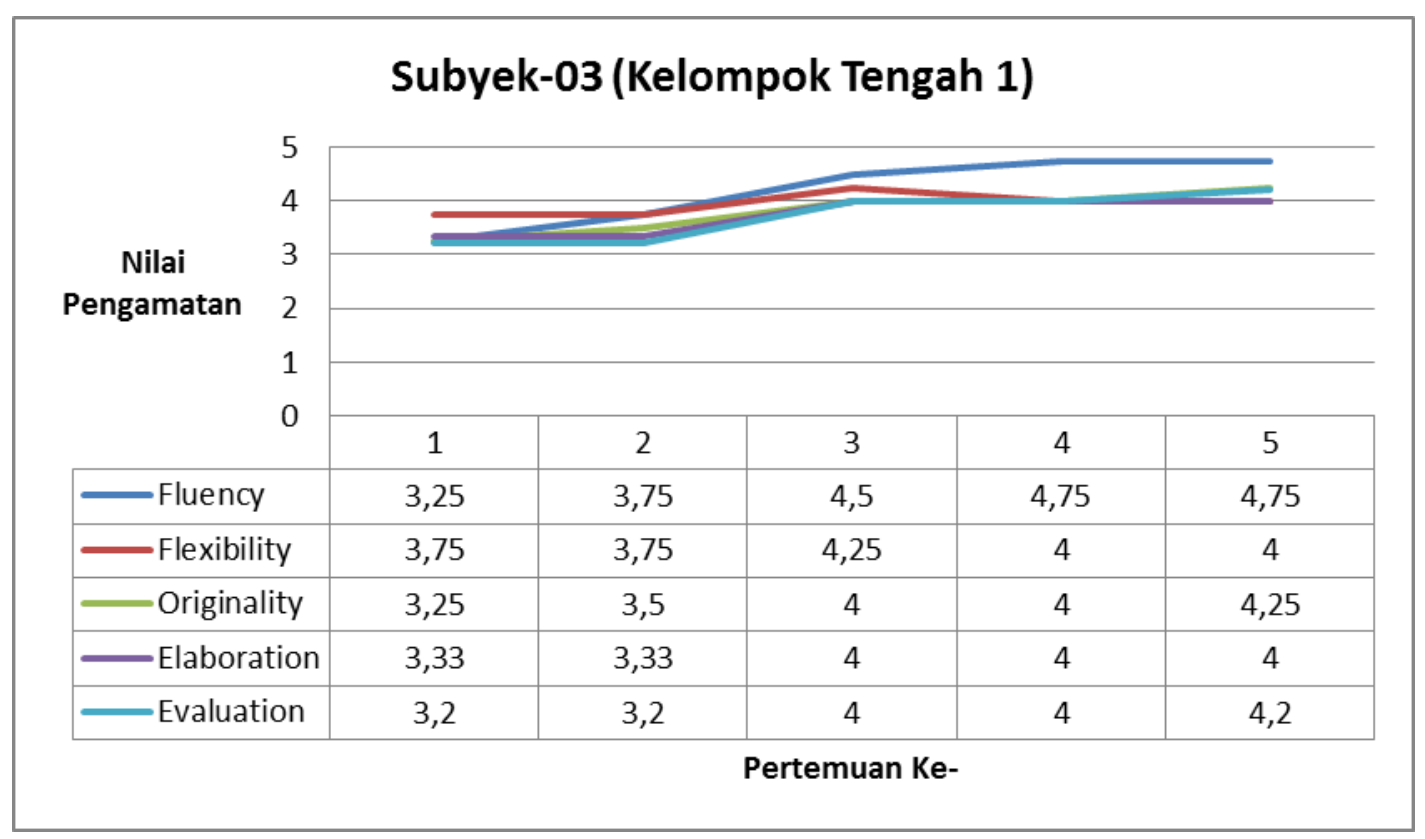

Gambar 1

Hasil Pengamatan Keterampilan berpikir kreatif S-03

Dari data diatas dapat diperoleh penjelasan bahwa pada pertemuan I, S-03 memperoleh rata-rata nilai hasil pengamatan pada semua indikator cukup tinggi yaitu pada angka diatas 3,00 , hal ini menunjukan bahwa, S-03 sudah mempunyai keterampilan berpikir kreatif belajar yang cukup baik. Setiap indikator dari pertemuan I sampai pertemuan $\mathrm{V}$ rata-rata mengalami peningkatan yang bervariasi, meskipun ada juga indikator yang statis seperti terlihat pada indikator elaboration (keterperincian) pada pertemuan III sampai pertemuan V. Secara keseluruhan grafik diatas tidak ada penurunan pada tiap-tiap indikator, hal ini menunjukan bahwa S-03 mempunyai progress yang cukup baik dalam kaitannya dengan strategi peningkatan keterampilan berpikir kreatif belajar.

Peningkatan besar terjadi pada indikator evaluation di pertemuan II yang semula 3,20 menjadi 4,00 pada pertemuan III, peningkatan ini menandakan bahwa pada pertemuan II sampai pertemuan III S-03 telah mampu menunjukan bahwa dirinya terampil dalam menyimpulkan atau mengevaluasi hasil kerja penyelesaian masalahnya.

Berdasarkan penjelasan diatas bahwa hampir semua indikator keterampilan berpikir kreatif pada S-03 mengalami peningkatan dalam pembelajaran matematika dengan menerapkan model SAVI berbasis discovery strategy. Hal ini pula ditunjukkan dengan hasil perhitungan gain selama proses pembelajaran yang dilakukan oleh peneliti.

Hasil pengamatan keterampilan berpikir kreatif S-03 yang diperoleh dari lembar pengamatan keterampilan berpikir kreatif yang selanjutnya diolah dengan rumus gain ternormalisasi, ditunjukkan oleh tabel berikut:

Tabel.2

Gain Ternormalisasi Keterampilan berpikir kreatif S-03

\begin{tabular}{|l|l|l|}
\hline $\begin{array}{l}\text { Gain } \\
\text { Ternormalisa } \\
\text { si }\end{array}$ & $\begin{array}{l}\text { Perhitunga } \\
\text { n }\end{array}$ & $\begin{array}{l}\text { Kriteri } \\
\mathbf{a}\end{array}$ \\
\hline $\begin{array}{l}\text { Gain I (dari } \\
\text { pertemuan 1 ke } \\
\text { 2) }\end{array}$ & 0,09 & Rendah \\
\hline $\begin{array}{l}\text { Gain II (dari } \\
\text { pertemuan 2 ke 3) }\end{array}$ & 0,43 & Sedang \\
\hline $\begin{array}{l}\text { Gain III (dari } \\
\text { pertemuan 3 ke 4) }\end{array}$ & 0,00 & Rendah \\
\hline $\begin{array}{l}\text { Gain IV (dari } \\
\text { pertemuan 4 ke 5) }\end{array}$ & 0,12 & Rendah \\
\hline
\end{tabular}

Untuk selengkapnya mengenai perhitungan indeks gain S-03 dapat dilihat pada lampiran D.4 mengenai rekapitulasi indeks gain keterampilan berpikir kreatif S-03. 
Berdasarkan tabel diatas, hampir semua peningkatan gain dari S-03 berkategori rendah bahkan gain III (pertemuan 3 ke pertemuan 4) besar nilai gain hanya 0,00 namun bukan berarti bahwa pada pertemuan tersebut S-03 tidak mampu berpikir kreatif hanya saja mungkin tidak ada perubahan atau sangat statis

Sedangkan untuk gain II mencapai peningkatan sebesar masingmasing 0,43 dengan kriteria sedang. Hal ini menunjukan adanya loncatan yang cukup signifikan tentang peningkatan keterampilan berpikir kreatif belajar. Terdapat banyak faktor yang mempengaruhi peningkatan normalitas gain. Faktor-faktor tersebut dibahas melalui wawancara.

Dari pengumpulan data melalui pengamatan ataupun wawancara secara mendalam diperoleh informasi bahwa S-03 merupakan siswa yang mempunyai keterampilan berpikir kreatif cukup baik, hal ini dibuktikan dari lembar jawaban dari soal yang diberikan oleh peneliti

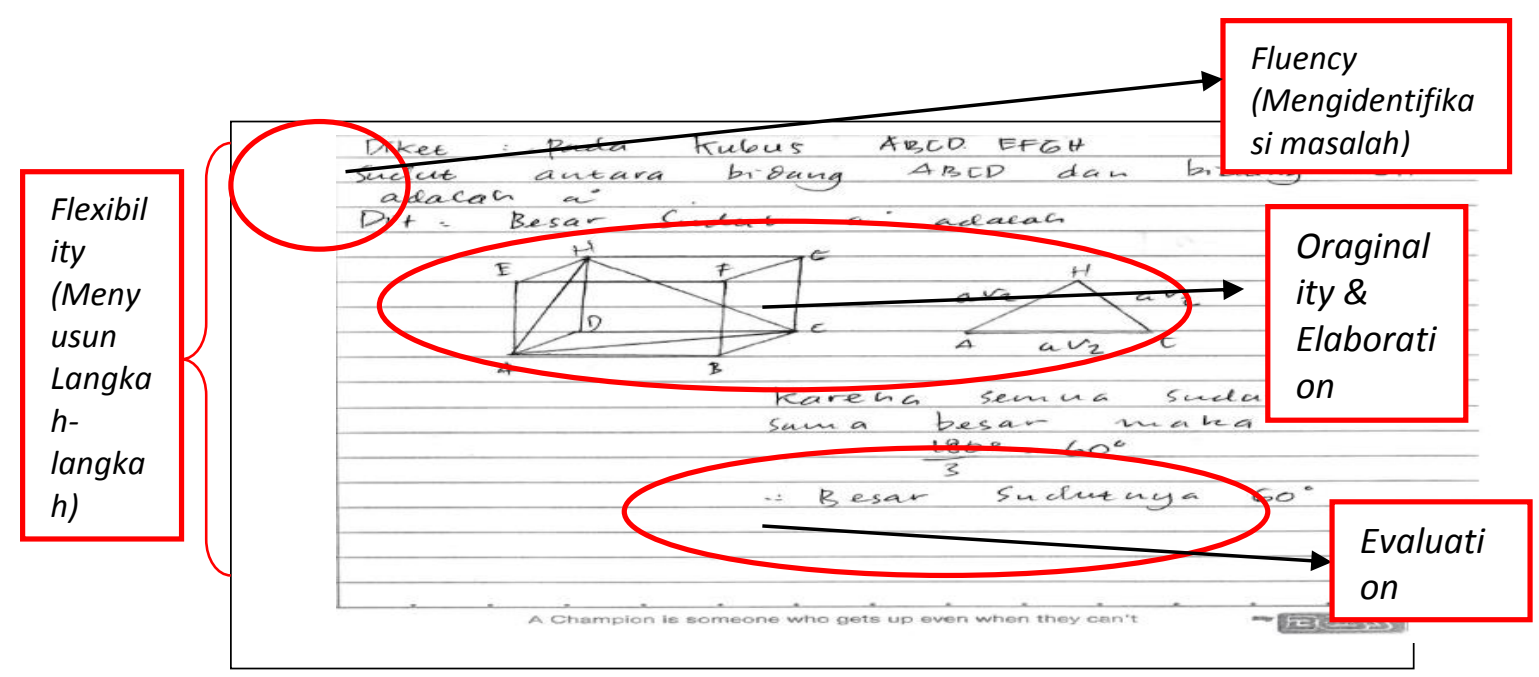

Gambar 2.

Hasil keterampilan berpikir kreatif S-03

Dari gambar diatas diperoleh informasi bahwa S-03 sudah terampil dalam menuliskan apa yang diketahui dan ditanya. Hal ini sudah memenuhi indikator berpikir lancar (fluency) yaitu keterampilan untuk mengidentifikasi permasalahan. Selain itu, S-03 juga terampil melukiskan gambar kubus pada lembar jawaban sebagai wujud ide dari keterampilan flexibility yaitu keterampilan dalam menginterpretasikan/menafsirkan suatu permasalahan dengan bantuan gambar.

S-03 mampu menggunakan konsep mengevaluasi jawaban ditandai dengan menuliskan rangkuman dari jawaban yang telah dikerjakan, artinya $\mathrm{S}$ 03 memiliki keterampilan mengevaluasi (evaluation). Namun keterampilan dalam memperinci jawaban secara runtut disertai langkah-langkahnya kurang tepat.
Lebih lanjut mengenai analisa tentang keterampilan berpikir kreatif S-03 dapat dilihat dari hasil wawancara antara peneliti dengan S-03, sebagai berikut:

P : " Pada saat mengerjakan soal, kamu mengerjakan dengan runtut atau tidak?" (dari menuliskan diketahui, ditanyakan dan dijawab)

S-03 : "Iya pak, kan disuruh pak guru gitu”.

$\mathrm{P} \quad$ : “ Owh begitu yah, kamu merasa kesulitan gak disuruh mengerjakan secara runtut?"

S-03 : “Gak pak”.

$\mathrm{P} \quad$ : “ Bagaimana cara kamu memahami pertanyaan-pertanyaan yang ada

pada soal?" (memberikan penafsiran/interpretasi terhadap soal) 
S-03 : “ Dibaca pelan-pelan pak sambil dipikirkan apa yang ditanyakan.”

$\mathrm{P} \quad$ : " Digambar tidak? Kalau iya, tujuannya apa?"

S-03 : “Iya pak, biar lebih jelas”.

$\mathrm{P} \quad$ : “ Apakah diakhir penyelesaian soal, kamu selalu menyimpulkan jawaban yang sudah kamu temukan?"

S-03 : “Iya pak”.

Berdasarkan hasil pengamatan maupun wawancara dan cuplikan lembar jawaban, S-02 telah memiliki keterampilan berpikir kreatif cukup baik terbukti dari hasil pengamatan yang menunjukan peningkatan keterampilan dari tiap pertemuan sampai pada analisa hasil lembar jawaban dan wawancara meskipun terkadang S-03 masih ceroboh/kurang rinci dan salah dalam menentukan langkahlangkah penyelesaian.

Sedangkan secara keseluruhan hasil pengamatan dan wawancara terhadap 6 siswa pilihan adalah sebagai berikut:

Tabel 3.

Rekapitulasi Nilai Keterampilan Berpikir Kreatif

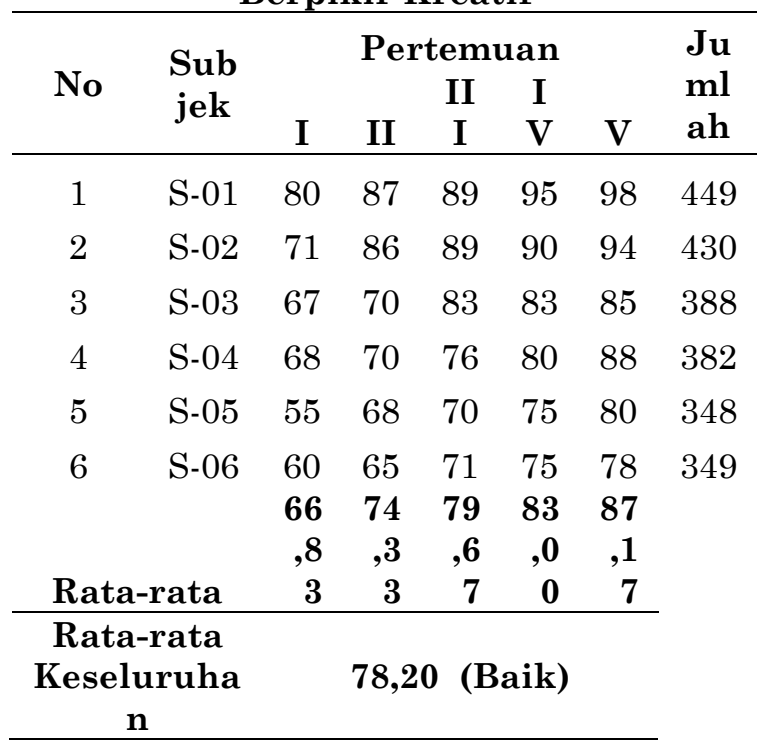

Dari data tabel diatas, peneliti menyimpulkan bahwa terdapat peningkatan keterampilan berpikir kreatif pada pembelajaran dengan menggunakan model SAVI berbasis discovery strategy materi dimensi tiga kelas $\mathrm{X}$ pada subyek kelompok tertentu.

\section{SIMPULAN}

Pembelajaran matematika dengan pendekatan model SAVI berbasis discovery strategy pada materi dimensi tiga kelas $\mathrm{X}$ dalam penelitian ini memfokuskan subjek penelitian pada enam siswa pilihan penelitian Instrimen yang digunakan pada penelitian pembentukan karakter kemandirian yaitu menggunakan lembar observasi dan pedoman wawancara. Teknik pengolahan data dengan menggunakan uji gain dan triangulasi. Berdasarkan teknik pengumpulan dan pengolahan data menunjukan bahwa keterampilan berpikir kreatif dapat dibentuk dengan menggunakan pendekatan model SAVI berbasis discovery strategy yang pembelajarannya disusun sedemikian rupa agar siswa mampu berinteraksi dengan baik , berantusias, berimajinasi tinggi untuk menemukan hal-hal baru dan dapat mengembangkan pemahamannya dalam menyelesaikan masalah.

\section{SARAN}

Dari hasil penelitian penelitian dapat memberikan saran yaitu instrumen yang dikembangkan seharusnya dibuatkan pedoman penskoran yang baik dan tepat disesuaikan dengan kemampuan siswa, pengambilan data penelitian dapat dilakukan dengan bantuan guru atau orang tua siswa terkait dengan pembentukan karakter kemandirian.

\section{DAFTAR PUSTAKA}

Ahmadi. IK., Setyono, H.A., dan Amri, S. 2011. Pembelajaran Akselerasi (Analisis Teori dan Praktek Serta Pengaruhnya Terhadap Mekanisme Pembelajaran dalam Kelas Akselerasi). Jakarta: Prestasi Pustaka Publisher.

Baker, M., Rudd, R., and Pomeroy, C. 2001. Relationship Between Critical and Creative Thinking. Journal of Southern Agricultural Education Research.Volume 51. No. 1.

Mudjiman, H. 2009. Belajar mandiri. Surakarta: UNS Press

Postman, N. 2002. Matinya Pendidikan, Redifinisi Nilai-Nilai Sekolah. Yogyakarta: Jendela 
Rochmad. 2009. Pengembangan Model Pembelajaran : Mengacu Pada Plomp. $\quad$ http://Rochmadunnes.blogspot.com .

Siswono, T. 2008. Model Pembelajaran Matematika Berbasis Pengajuan dan Pemecahan Masalah Untuk Meningkatkan Kemampuan Berpikir Kreatif. Surabaya: Unesa University press

Sudjana. 2005A. Metode Statistika. Bandung: Tarsito.

Sugiyono. 2007. Metode Penelitian Pendidikan Pendeketan Kuantitatif, Kualitatif, dan $R \& D)$. Bandung: Alfabeta.

Sukestiyarno. 2012. Olah Data Penelitian Berbantuan SPSS. Semarang : Universitas Negeri Semarang.

Trianto. 2007. Model Pembelajaran Terpadu dalam Teori dan Praktek. Jakarta: Prestasi Pustaka.

Wang, A.Y. 2011. Contexts of Creative Thinking: A Comparation on Creative Performance of Student Teachers in Taiwan and United States. Journal of International and Cross-Cultural Studies. Volume 2, No.1. Hal 1-14. 